\title{
Anti-monuments to the Immemorial. Exploring the how, why, and what next of our relationship to our environment.
} Jessie Stanley post@jessiestanley.com

\begin{abstract}
Monuments typify human habitation of place, memorialising ideologies of the prevailing power from moments in time. In recent decades, their form has undergone a revolution. Along with their transformation from the heavy permanence of monumentality, to the temporality of anti-monumental form - subject matter has also diametrically shifted from representing the state, to representing the marginalised. My practice-based research explores further the anti-monuments' potential for social activism - to expand memorialisation beyond a human-centric narrative, to acknowledge the immemorial forces that shape place over deep time. An iterative creative process informs the major body of site-responsive works Human/Nature undertaken as Artist in Residence at Kyneton Botanic Gardens in regional Victoria, Australia, presented at the Kyneton Contemporary Art Triennial 2018.

Drawing on the site's deep time environmental and ideological origins as transformative forces, I created a series of anti-monuments: activating public space as an experimental laboratory to explore and discover the how, why, and what next of our relationship to our environment.
\end{abstract}

Keywords: social activism, public space, place, human-nature relationship, monument/anti-monument, deep time

To cite this article:

Stanley, J. (2019). Anti-monuments to the Immemorial. Exploring the how, why, and what next of our relationship to our environment. The Journal of Public Space, 4(3), I55-I70, DOI

10.3289|/jps.v4i3.1227

This article has been double blind peer reviewed and accepted for publication in The Journal of Public Space. (c) (i) (5) This work is licensed under a Creative Commons Attribution - Non Commercial 4.0 International License https://creativecommons.org/licenses/by-nc/4.0/ 
First Things First: activism and public space.

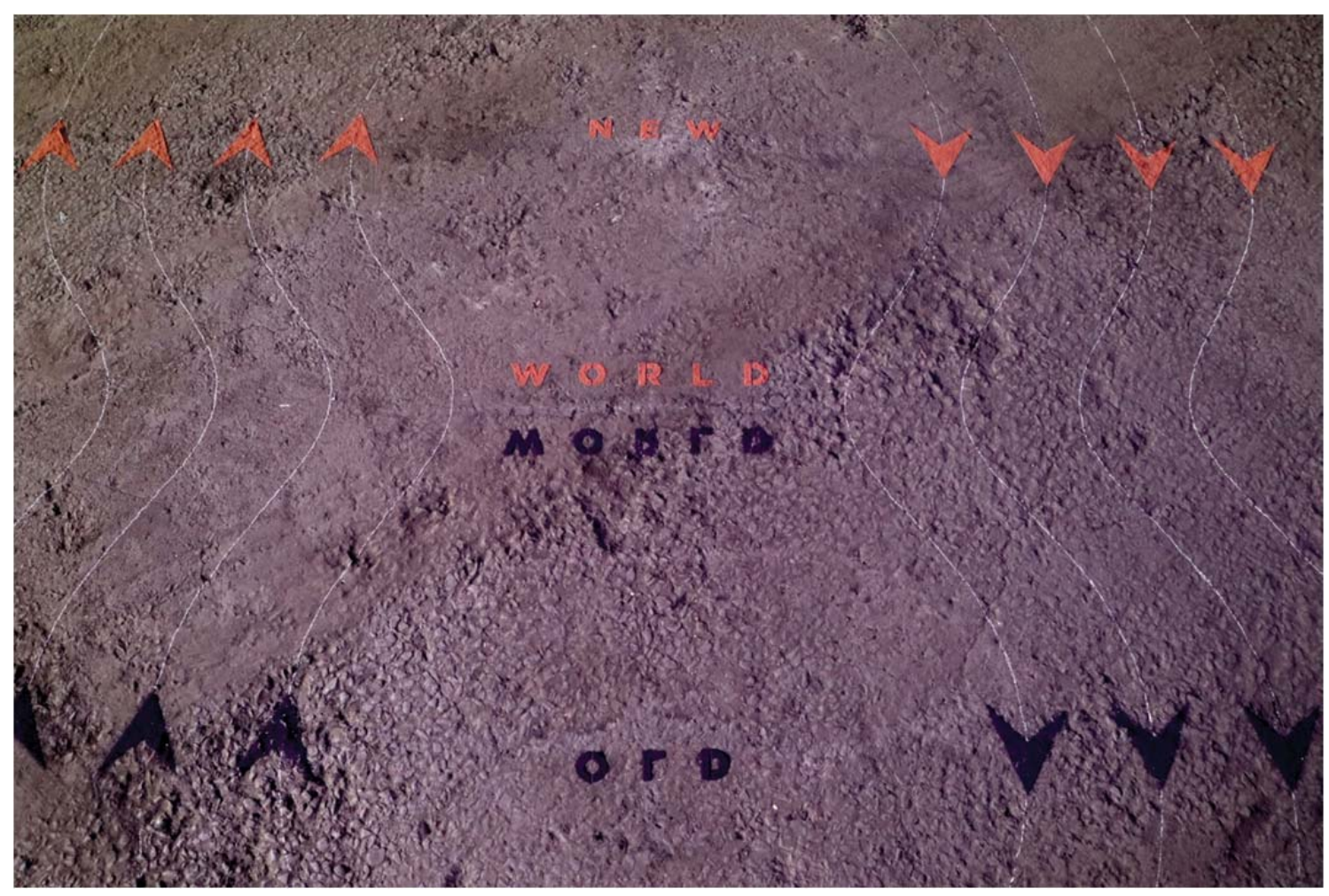

Figure I. Detail of Human/Nature, Act O I: Native/Foreign, Old World/New World. Photograph Jessie Stanley.

Framing the way I approach activism and public space in my arts practice, is my background in graphic design and alignment with the First Things First Manifesto 2000 (Kalman, Lasn, et al 1999).

The manifesto was re-issued when I was midway through my graphic design studies in 2000. Its impassioned declaration for a paradigm shift in graphic design - to serve public over private interests - beautifully articulated the potential I saw in graphic design to help shape a better world. The original manifesto (written and published by Ken Garland in 1964) summarised a growing unease with the entanglement of graphic design with global consumerism, and their saturating effect on public consciousness through television, press, radio, and billboard advertising. Its re-issue by a new generation of designers reiterated this dissatisfaction with graphic design's role in saturating public space and challenged graphic designers to utilise their communication skills to engage in work championing democracy and curiosity.

"Designers who devote their efforts primarily to advertising, marketing and brand development are supporting, and implicitly endorsing, a mental environment so saturated with commercial messages that it is changing the very way citizen-consumers speak, think, feel, respond and interact. To some extent we are all helping draft a reductive and immeasurably harmful code of public discourse."

(Kalman, Lasn, et al 1999) 
It situated the predominant function of graphic design as shaping and occupying a public space that symbiotically championed consumerism, whilst it drowned out more pressing issues of our time: "unprecedented environmental, social and cultural crises" (Kalman, Lasn, et al, 1999). It indelibly impressed upon me the role that graphic designers can play in positively (or negatively) affecting the way meaning is produced within society:

"We propose a reversal of priorities in favour of more useful, lasting and democratic forms of communication - a mindshift away from product marketing and toward the exploration and production of a new kind of meaning. The scope of debate is shrinking; it must expand. Consumerism is running uncontested; it must be challenged by other perspectives expressed, in part, through the visual languages and resources of design". (Kalman, Lasn, et al 1999)

Since first reading these words l've spent much time deliberating and experimenting with how I might use my skills as a visual communicator to create "more useful, lasting and democratic forms of communication" (Kalman, Lasn, et al, 1999). Upon graduating, I undertook internships aligned with the manifesto. First, I travelled to Fabrica in Treviso, Italy - a unique communication research centre for under 25 year-olds to develop and test ideas for communication works as vehicles of social change (founded by Luciano Benetton, it's also the home of Colors magazine founded by signatory Tibor Kalman). I then travelled to The Hague in the Netherlands for an internship at Studio Dumbar (founded by signatory Gert Dumbar) - a more traditional design studio that creates communication material for private and cultural institutions such as banks, telcos, galleries, and publishing houses.

Bringing these experiences home, I formed a design studio, Foundry (2003-20 I 2), in my hometown of Melbourne, Australia. Its focus was to co-opt the private space of marketing communications, into opportunities to expand our understanding of the world around us - to communicate ideas that matter. I found like-minded clients who supported my approach - creating communication material ranging from a visual exploration of the mathematical structure of roses for an Aesop product; an artist's book for Spicers Paper's 'Starwhite' range featuring an extrapolation of Drake's equation (which estimates the number of planets in the universe that have intelligent life forms); to a poster series for Oxford University communicating their research findings on genetic variation in the UK.

Gradually commissions came along that afforded more autonomous creative freedom, pre-empting me to refocus my practice. Today, I situate my practice as an artist/designer intervening in public space, with "useful, lasting and democratic forms of communication" (Kalman, Lasn, et al, 1999). Shifting the context of my practice from the commercial industry of graphic design to the cultural life of public space, continues to open up new and exciting ways of giving voice and attention to the pressing issues highlighted in the manifesto: "unprecedented environmental, social and cultural crises" (Kalman, Lasn, et al, 1999).

Today in 2019, it is imminent that humans will be declared as the most dominant force in shaping environmental change; heralding a new epoch coined the Anthropocene (Carrington, 2016). In order to shape a more sustainable future we must urgently rethink our relationship with our environment. By situating narratives about the 
environment and human kind within public space, the human construct of 'place' is contextualised. Within my research intensive, site responsive practice, I contest and renegotiate our relationship with shaping place. Drawing on historiographic, geographic and scientific research, I create site responsive installations that temporarily co-opt place into an experimental lab - where we can test, explore, and discover the how, why, and what next of our relationship to our environment.

\section{Place}

The term 'place' originated in c. 400 BCE, with Plato and Aristotle philosophising about 'inhabited Earth'. Each viewed place as being an ontological condition for existence, as 'the ground for existence itself' (Cresswell 2015: 26). Today, place is a subject of debate across many disciplines, including architecture, philosophy, urban planning and ecology. My interest in place aligns with a geographical interpretation - describing the creative inertia of humans shaping their locality with its environmental assets and the tools at their disposal, driven by their ideologies. Place in this sense becomes 'a way of understanding the world' (Cresswell 20I5: 18), and 'is not simply something to be observed, researched and written about but is itself a part of the way we see, research and write' (Cresswell 20I5: 24).

\section{Place + time}

The phenomenon of monumentality is intrinsic to the genesis of place, as the prevailing power adorns their environment with memorials that celebrate their ideology. Marking moments in time, traditional monuments typically represent the desire of their benefactor to imprint a permanent legacy that reflects their position, power and influence. In their wake, Earth is littered with monuments - their meaning often forgotten or made irrelevant by the passage of time (Connerton, 2008; Savage, 1999; Winter, 1999). In this way, places assert a sense of time related to human life span (centuries, decades, or less), and the depth of our experience within them is contingent on the intelligibility and relevance of their symbolism.

The greater the extent of human development of our environments, the more removed we become from nature, and encountering a sense of time related to Earth's life span; 'geologic time' or 'deep time' (billions, millions or hundreds of thousands of years classified into aeons, eras, periods, epochs and ages). Accordingly, our opportunity to gain meaning and context by experiencing our sublime relationship to the astronomical scale of time and space becomes buried by place and concealed from our view (Grant, 2016; Hutton, cited in Farrier 2016; Marx, cited in Lefebvre, 1968).

Further to this, the way we experience place is now layered with a post-human relationship to technological tools, that mediate - and create an interface between physical, digital and virtual (Braidotti, Karvelas, 2018). Our smart phones have shifted our sense of time and place to a forever-changing luminous screen. Coupled with decades of consuming an avalanche of marketing messages, as the manifesto foretold, our attention span continues to shrink. And our concept of place becomes a decentralised, amorphous, abstracted reality, where we can be both here, and there, simultaneously. 
The durational tensions that co-exist within place fascinate me. Anchoring my works within place provides a relational context to broach these durational tensions. I draw upon the particularities of a place, to engage the audience in our changing relationship with our environment and sense of time.

\section{Place minus permanence: anti-monuments}

In recent decades commemorative form has undergone a revolution; diametrically shifting from representing the state, to representing the marginalised. In 1992, James $E$ Young coined the term 'counter-monument' to summarise this shift away from the emphasis of a memorial in public space from the monumental (a formal, tangible object to be venerated) to the contemporaneous (which instead invites audience contemplation, participation, and engagement: and emphasises their role in 'remembering' as the crucial element in completing the memorial) (Young, 1992; Hung, 2002; Froggett cited in Doherty, 20I5). Since Young's seminal coining of the term, the practice of redressing monumentality has flourished, and the term is applied to many methodologies. Of particular interest to my practice is the 'anti-monument': a form of commemoration in public space that typically draws attention to under-represented subjects, takes on temporary or horizontal form, is site responsive and engages visitors in temporal experience and meaning (Stevens, Franck, and Fazakerley 20I2).

Within my practice-based research l'm further exploring this potential of the antimonument for social activism. I create fleeting experiences with ephemeral materials that change the way we understand an environment - beyond a human-centric narrative, to acknowledge the immemorial forces that have shaped it over deep time.

\section{Human/Nature 2018}

As Artist in Residence at Kyneton Botanic Gardens, Victoria, Australia, for Kyneton Contemporary Art Triennial 2018, I researched its flora, geology and history, and consulted with the Friends of Kyneton Botanic Gardens and horticulturist Dr Peter May to inform a series of site-responsive, anti-monumental works. My ontological investigation aimed to trace the influence of humans and nature in shaping the Garden's site through space and deep time. By focusing this enquiry on the Gardens, I sought to reflect a broader narrative of how place evidences the sublime: "the world in a grain of sand' (Blake \& Washington, 1968).

'All of the elements found on Earth originate from the first few seconds of the Big Bang, and, the closer we look at the origins of life on Earth, the closer we come to understanding the inherent connectedness of the Universe.'

-Extract from audio Meteorological/Geological, Act 01: Native/Foreign, Ajax factory installation, Kyneton, Victoria, Australia (Stanley, 20I8)

Kyneton Botanic Garden's ordered landscaping and exotic plants from distant lands assert its colonial foundations and conceal the deep time geological transformations buried beneath it that support the areas agricultural success and are evident in the town's bluestone buildings. 
The series of site-responsive and interactive artworks I created invited visitors to participate in a narrative journey, to join me in tracing the origins of Kyneton Botanic Gardens through space and deep time. Divided into three acts, each could be experienced sequentially or autonomously. Act 0 I: Native/Foreign was situated in a derelict factory in Kyneton's industrial area. Act 02: Global/Universal and Act 03:

Space/Time were located in Kyneton Botanic Gardens. Visitors embarked on their journey at each with a map, and an audio guide accessible via Soundcloud.

\section{Act 01: Native/Foreign}

Ephemeral installation, various botanic and geologic materials, map, audio Location: Former Ajax Factory, 3I Beauchamp Street, Kyneton

The materials used to create this installation were distinctly tenuous. Botanic and geologic specimens from the Gardens, together with products of economic botany such as spices and pigments, created an interactive chart to explore, guided by the audio narrative. Coupled into dualities, they represented a focused sample of the relationship between humans and nature in shaping Kyneton Botanic Gardens, addressing themes of migration, colonisation, globalisation, acclimatisation, capitalism, legacy and extinction.

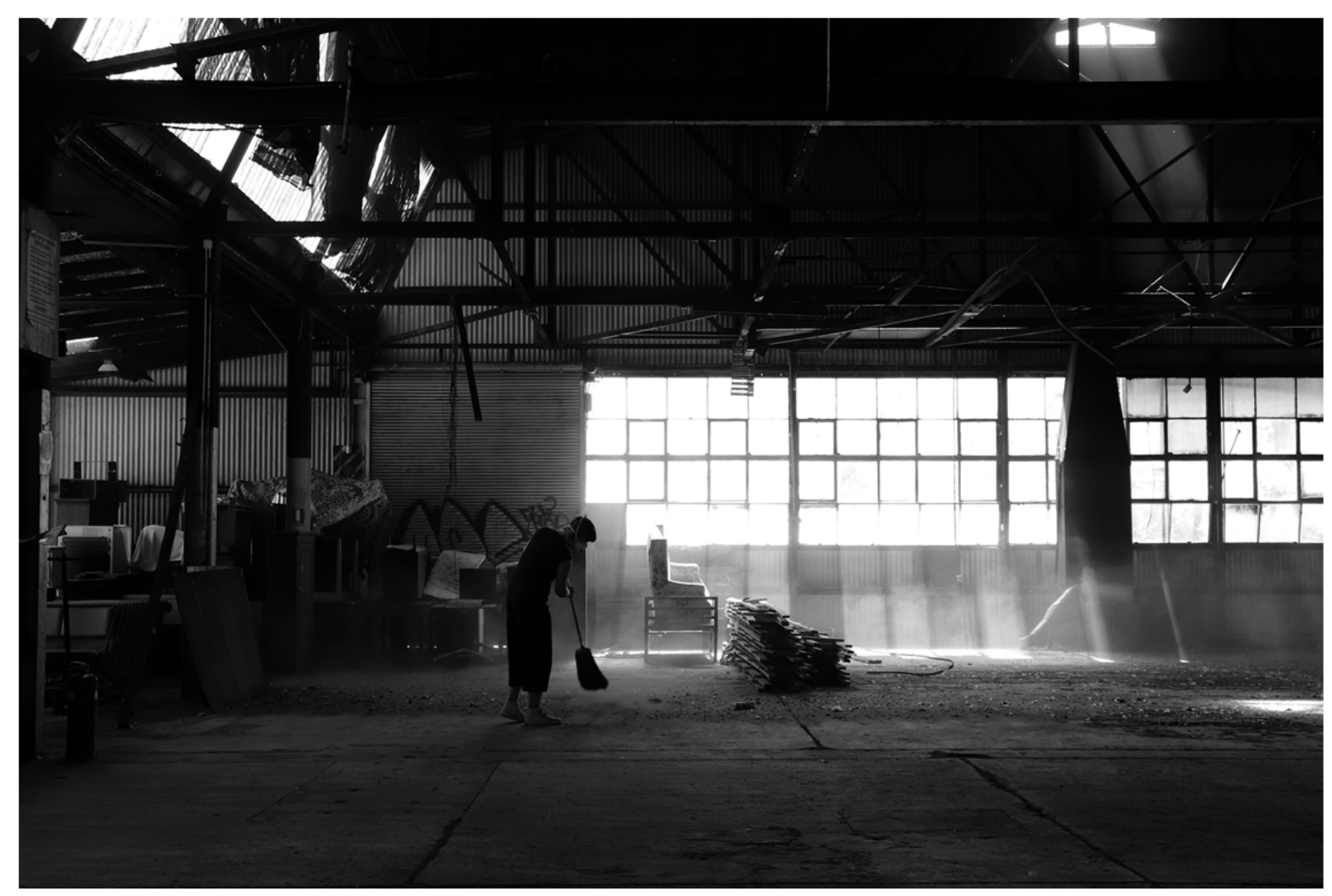

Figure 2. Jessie Stanley sweeping away years of accumulated dust in preparation for installation of Act 0 I: Native/Foreign at the Ajax Factory site. Photograph courtesy Missy Saleeba, 2018. 


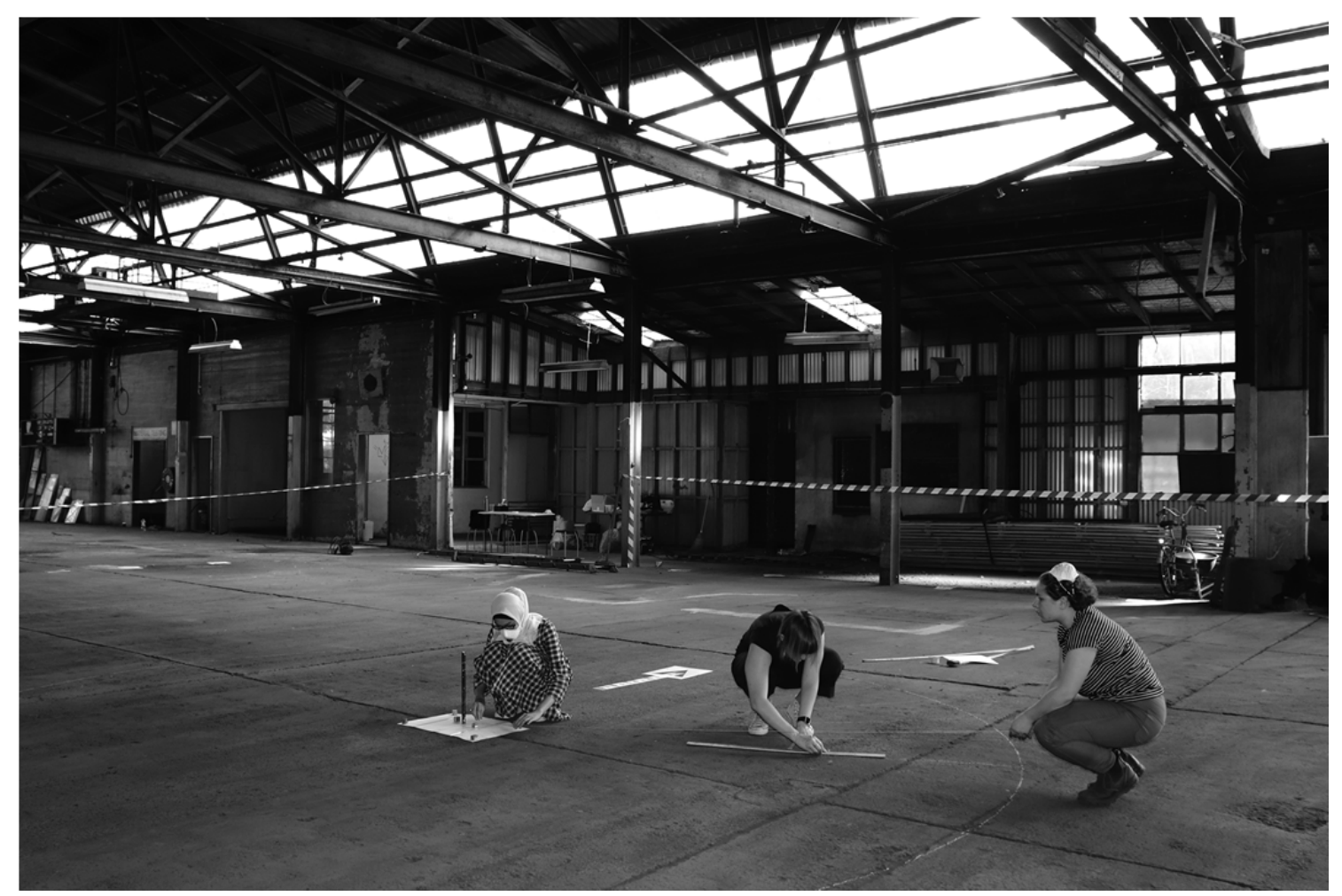

Figure 3. Installing Act 0I: Native/Foreign at the Ajax Factory site, Jessie Stanley with Mariah Bakhtiar and Jacqui Gordon. Photograph courtesy Missy Saleeba, 2018.
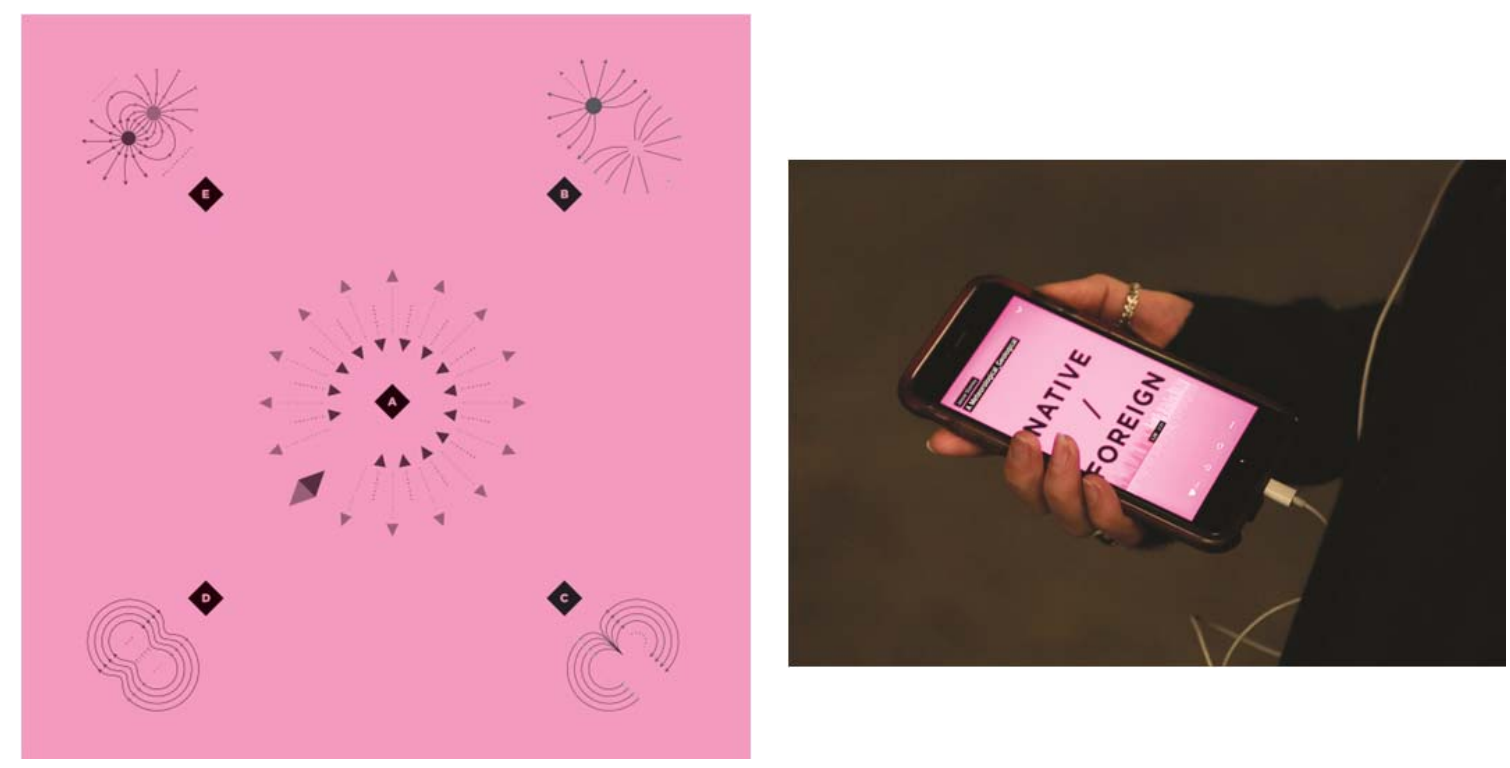

Figure 4 (on the left). Map detail, Floor plan of Act 0I: Native/Foreign, Jessie Stanley 2018. Figure 5 (on the right). Audio narrative for Act 0I: Native/Foreign accessed via Soundcloud. Photograph courtesy of Marc Eiden, 2018. 
Jessie Stanley

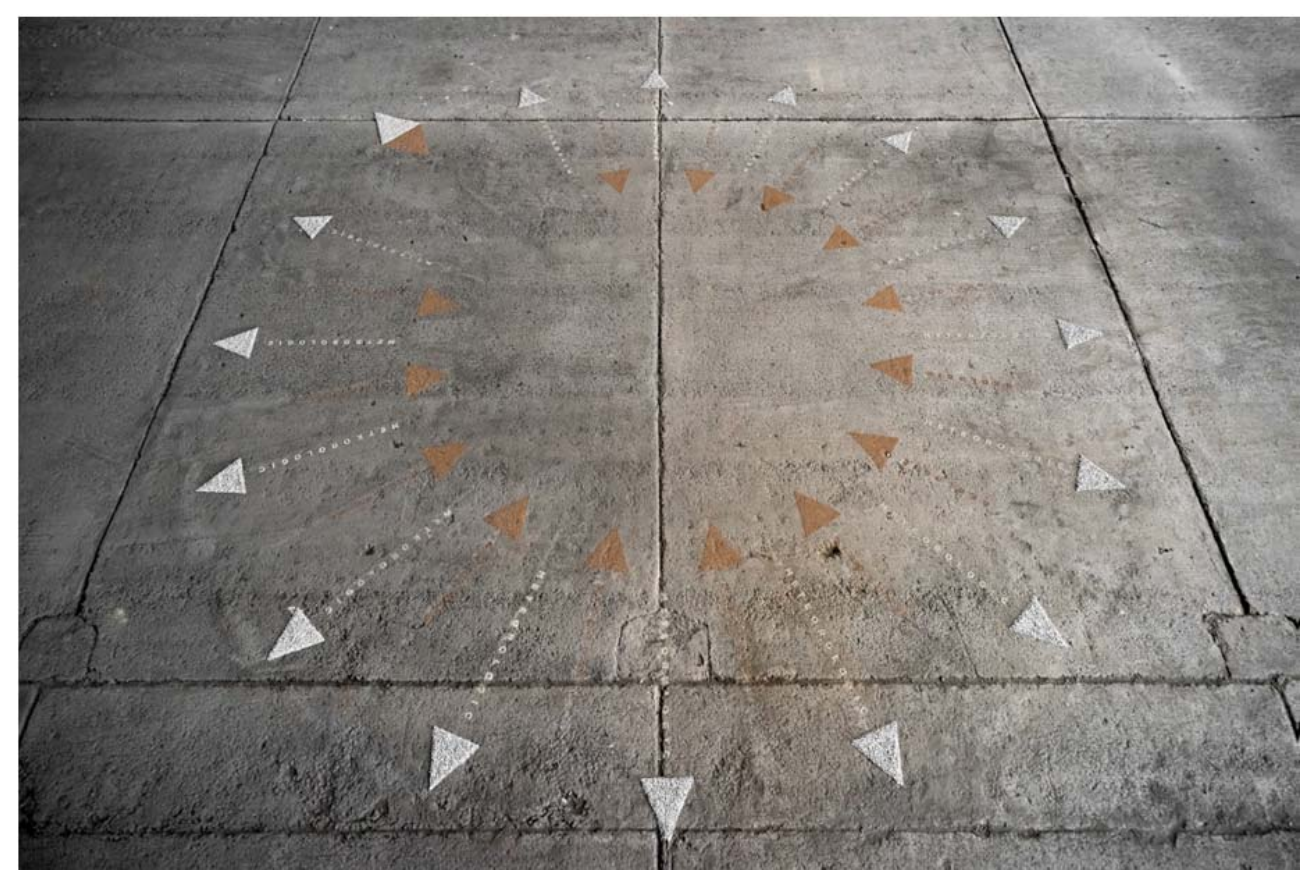

Figure 6. Human/Nature, Act 0I: Native/Foreign, Meteorologicall Geological,

Jessie Stanley 2018. Ephemeral installation, bluestone aggregate and dust, local brown and grey dermosol soil, 5.6x5.6m. Audio track 02:36. Former Ajax Factory, 3 I Beauchamp Street, Kyneton.

Photograph courtesy lan Hill.

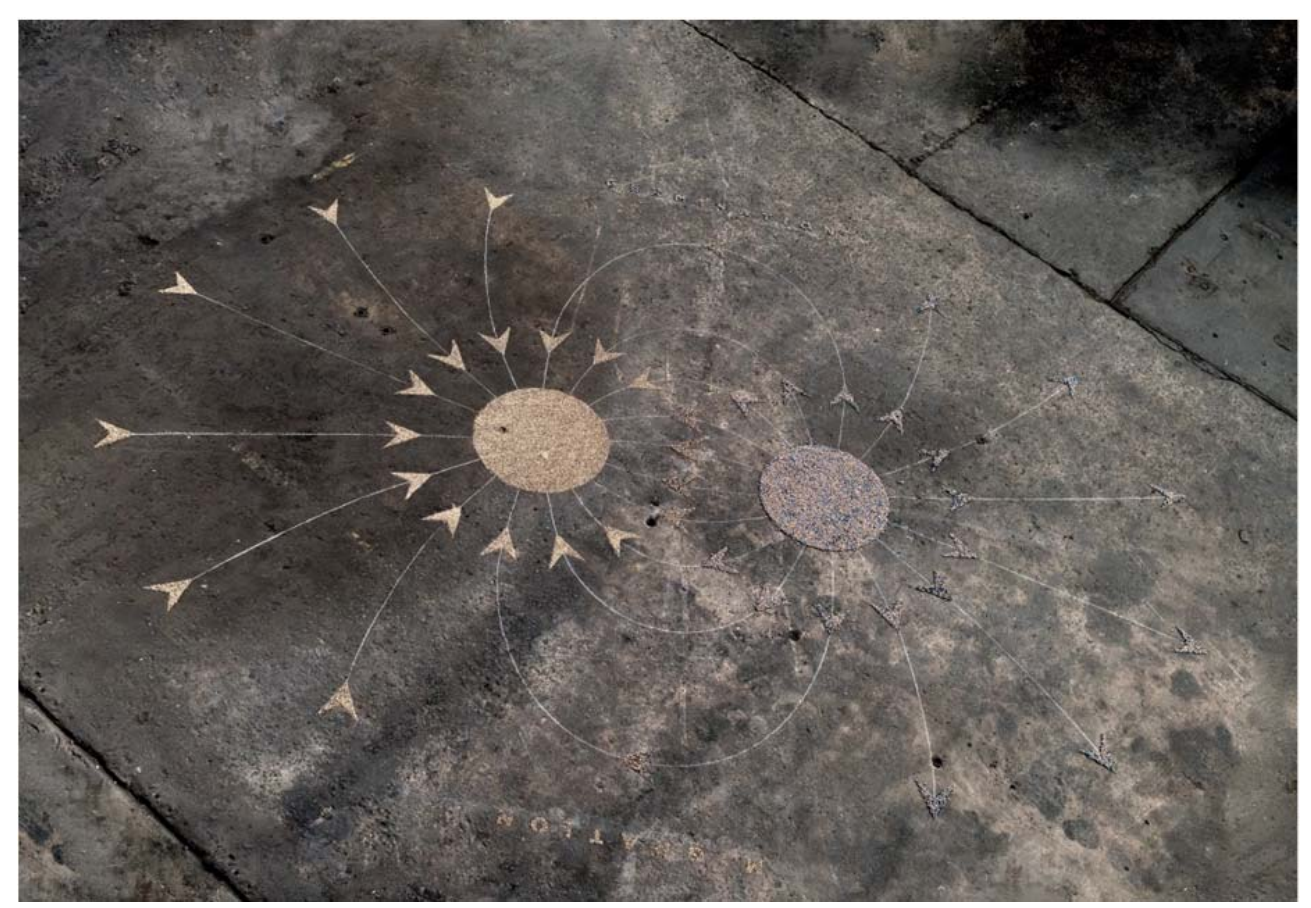

Figure 7. Human/Nature, Act 0I: Native/Foreign, Migration/Germination,

Jessie Stanley 2018. Ephemeral installation, Black pepper, lettuce, basil, coriander and broccoli seeds, chalk, 2.45x2.45m. Audio track 01:I6. Former Ajax Factory, 3I Beauchamp Street, Kyneton.

Photograph courtesy lan Hill. 


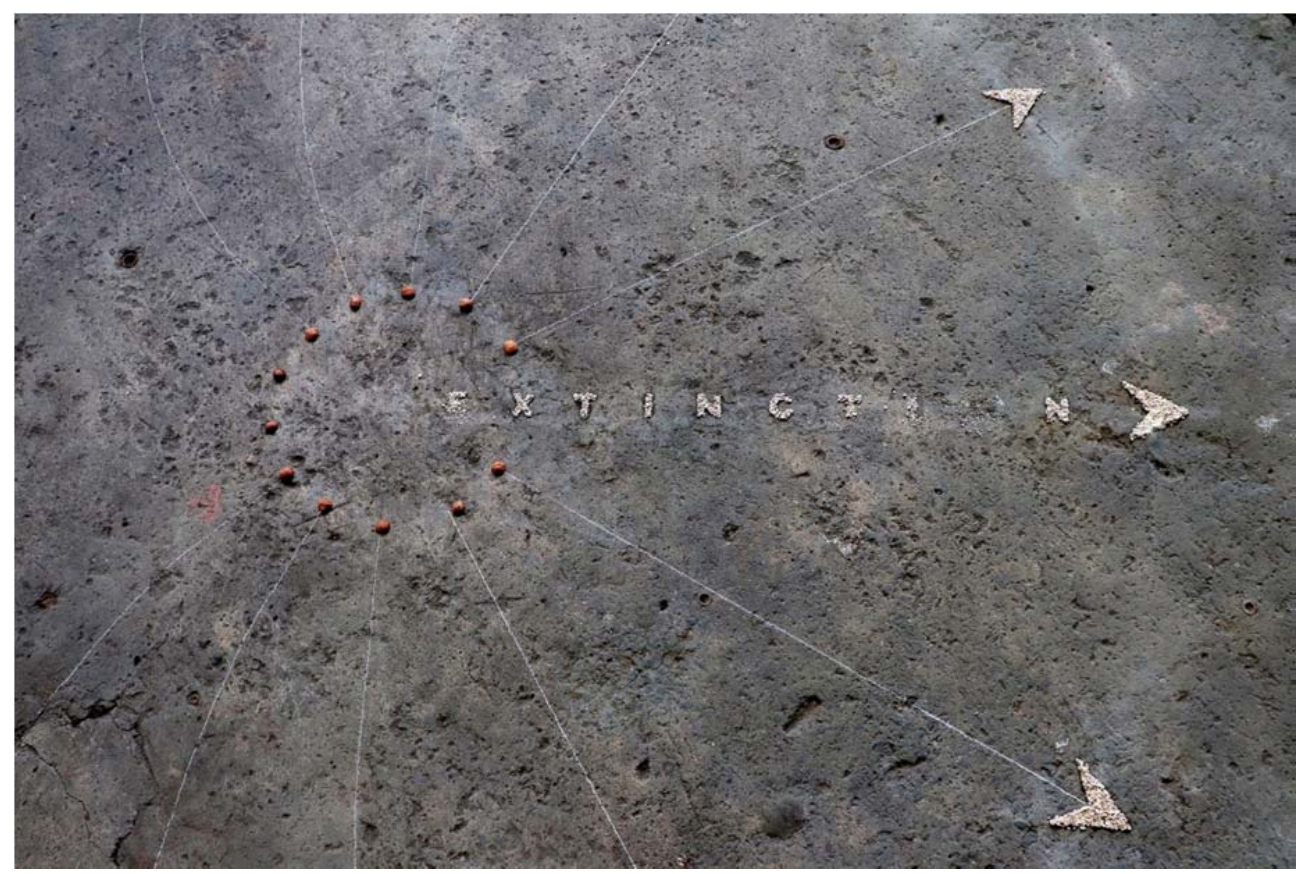

Figure 8. Detail of Human/Nature, Act 0I: Native/Foreign, Survival/Extinction. Photograph Jessie Stanley.

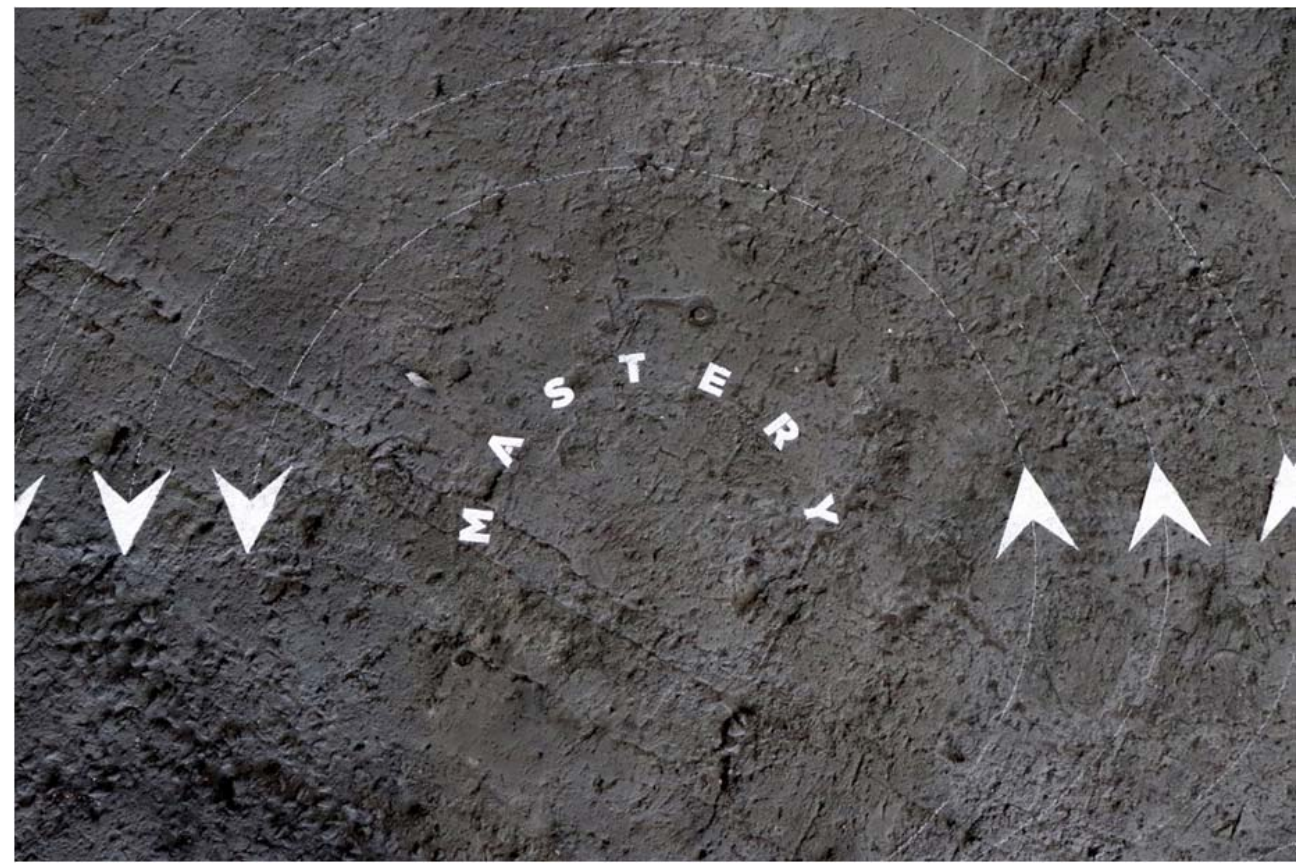

Figure 9. Detail of plain flour stencilled for Human/Nature, Act OI: Native/Foreign, Mastery/Harmony. Photograph Jessie Stanley. 


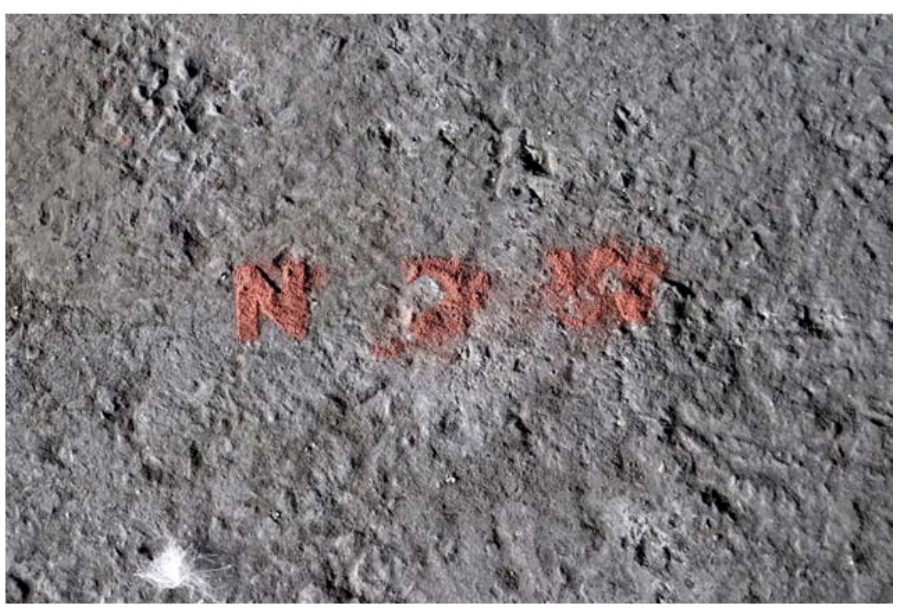

Figure 10. Detail of disintegration of Human/Nature, Act OI: Native/Foreign, Old World/New World.

Photograph Jessie Stanley.

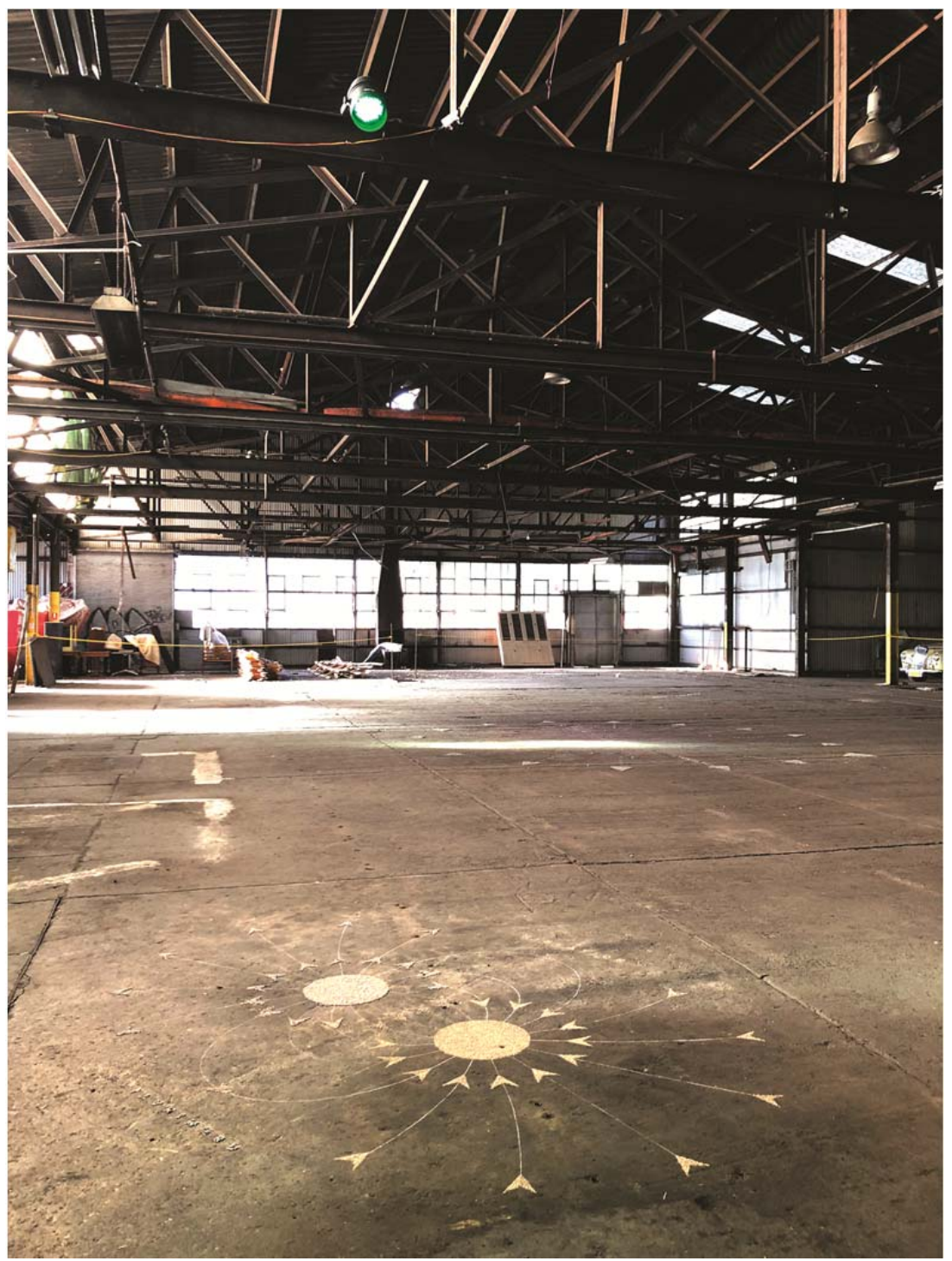

Figure I I. Human/Nature, Act O I: Native/Foreign, Migration/Germination in situ. Photograph courtesy Lauren Peters.

I64 | The Journal of Public Space, 4(3), 2019 | ISSN 2206-9658

City Space Architecture / UN-Habitat 


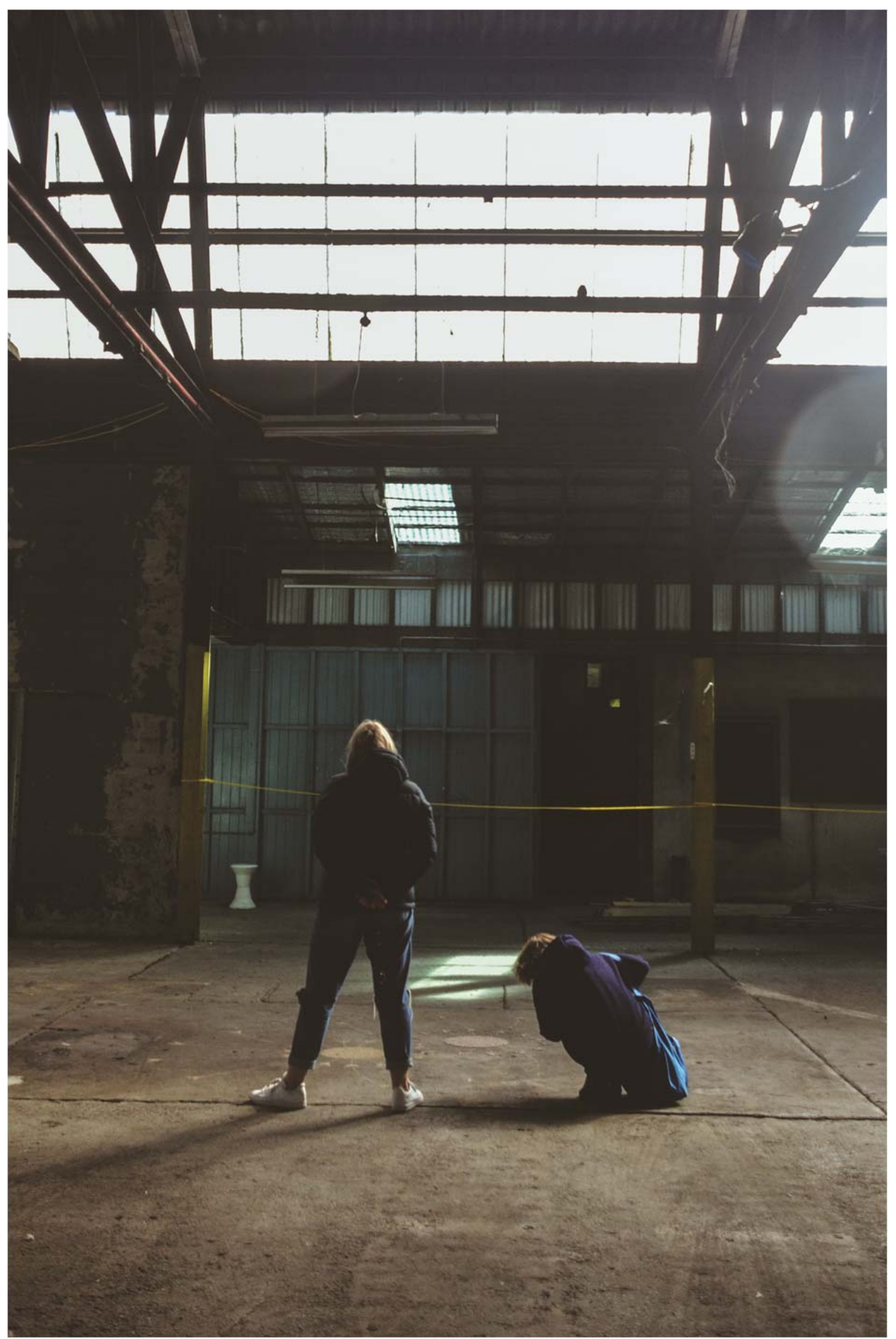

Figure 12. Visitors exploring Human/Nature, Act O I: Native/Foreign, Migration/Germination. $P$ hotograph courtesy Kyneton Contemporary Inc. 
Jessie Stanley

Act 02: Global/Universal

Projection installation, transparent vinyl

Location: Kyneton Botanic Gardens Cottage

This interactive installation transformed the cottage into an experimental lab broaching the colonisation of Mars. Projected light echoed the blue and red LEDs used to grow edible plants on the International Space Station. Filtered viewing through each coloured window pane concealed and revealed different elements within the projection, playing with the properties of light and the way we perceive colour to create illusions with form and text.

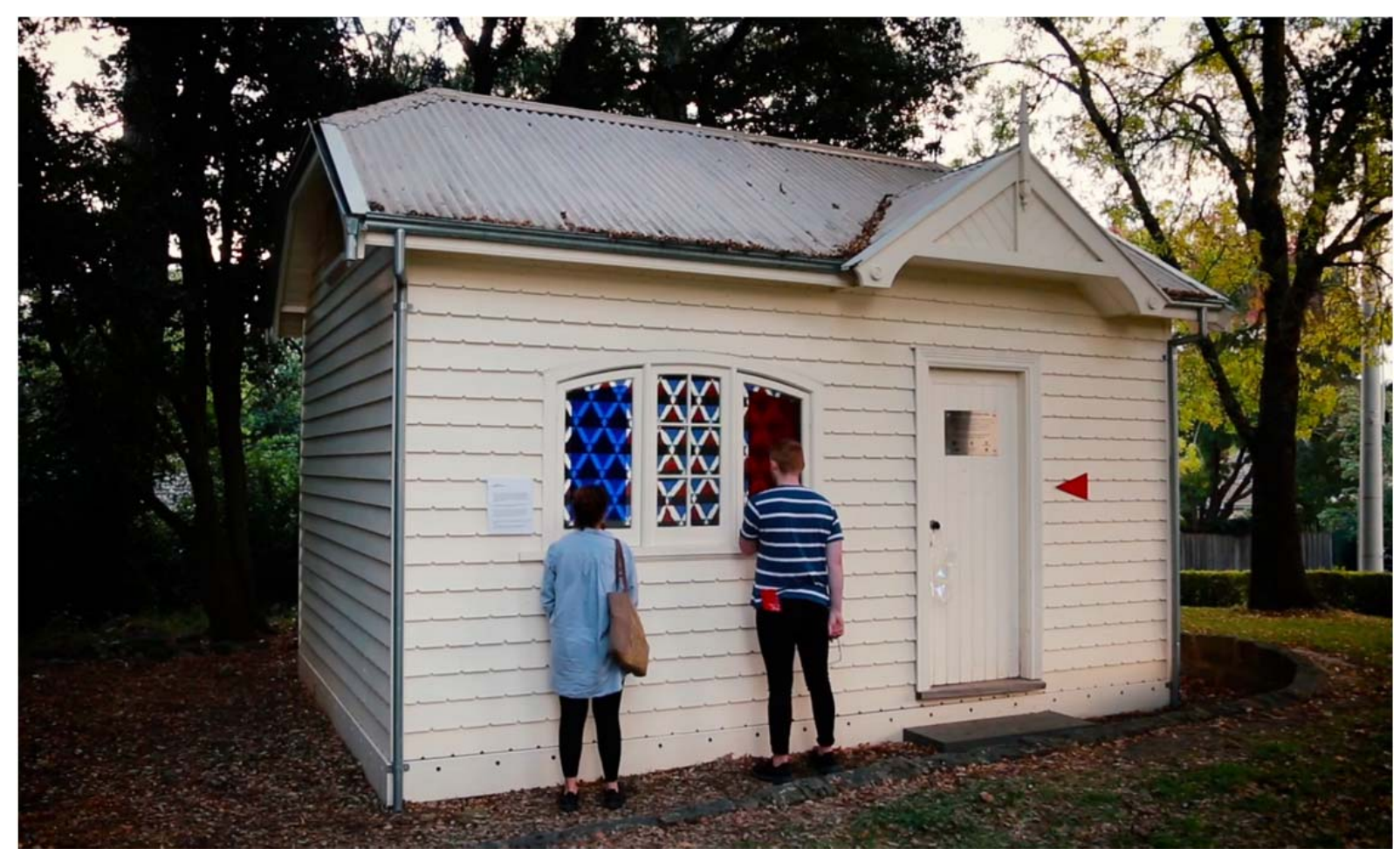

Figure 13. Visitors exploring the projection at the cottage: coloured filters on the cottage window panes transform the projected image of Human/Nature.

Act 02: Global/Universal. 


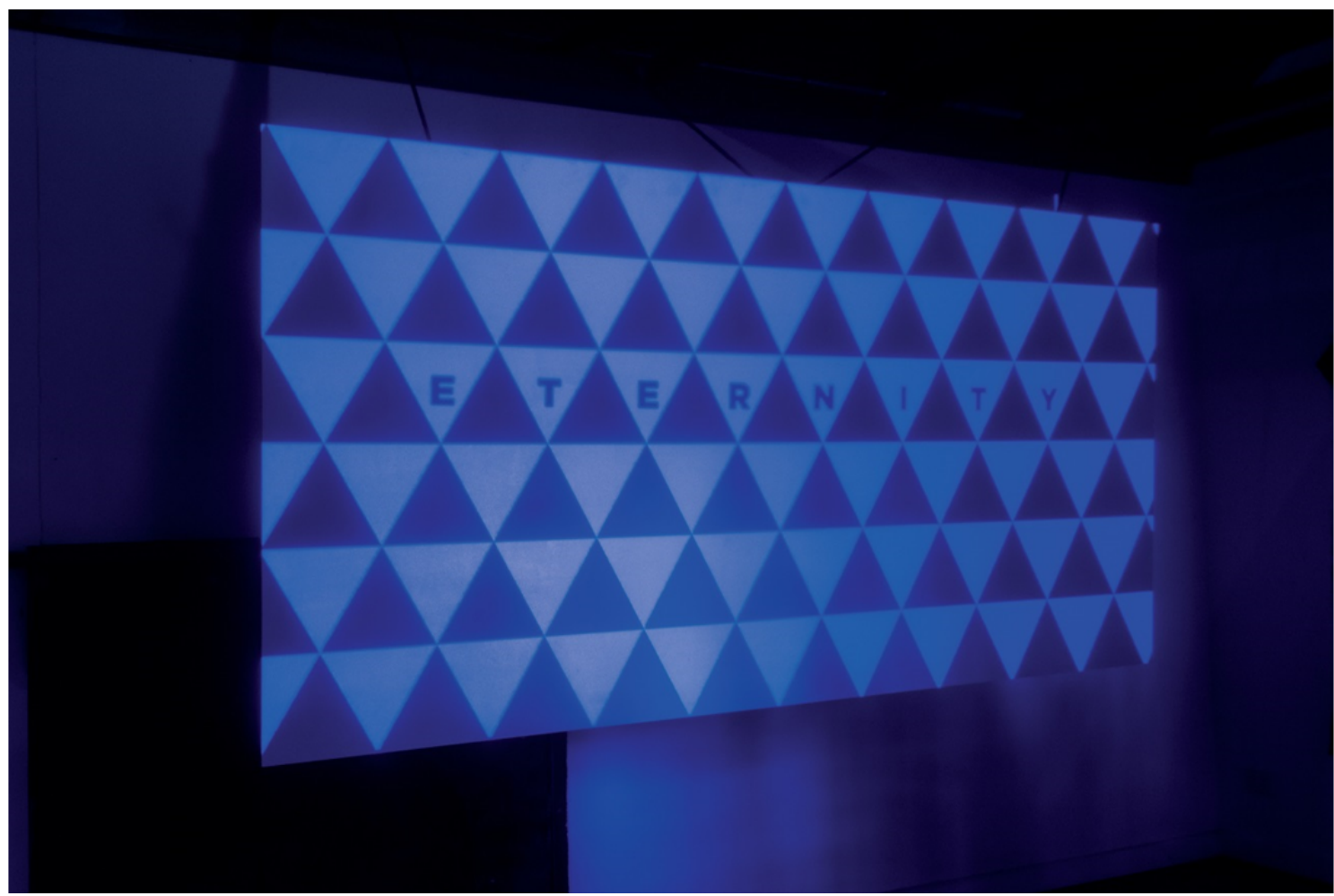

Figure I4. Projection as viewed through blue coloured window pane, Human/Nature, Act 02: Global/Universal. Photograph courtesy lan Hill.

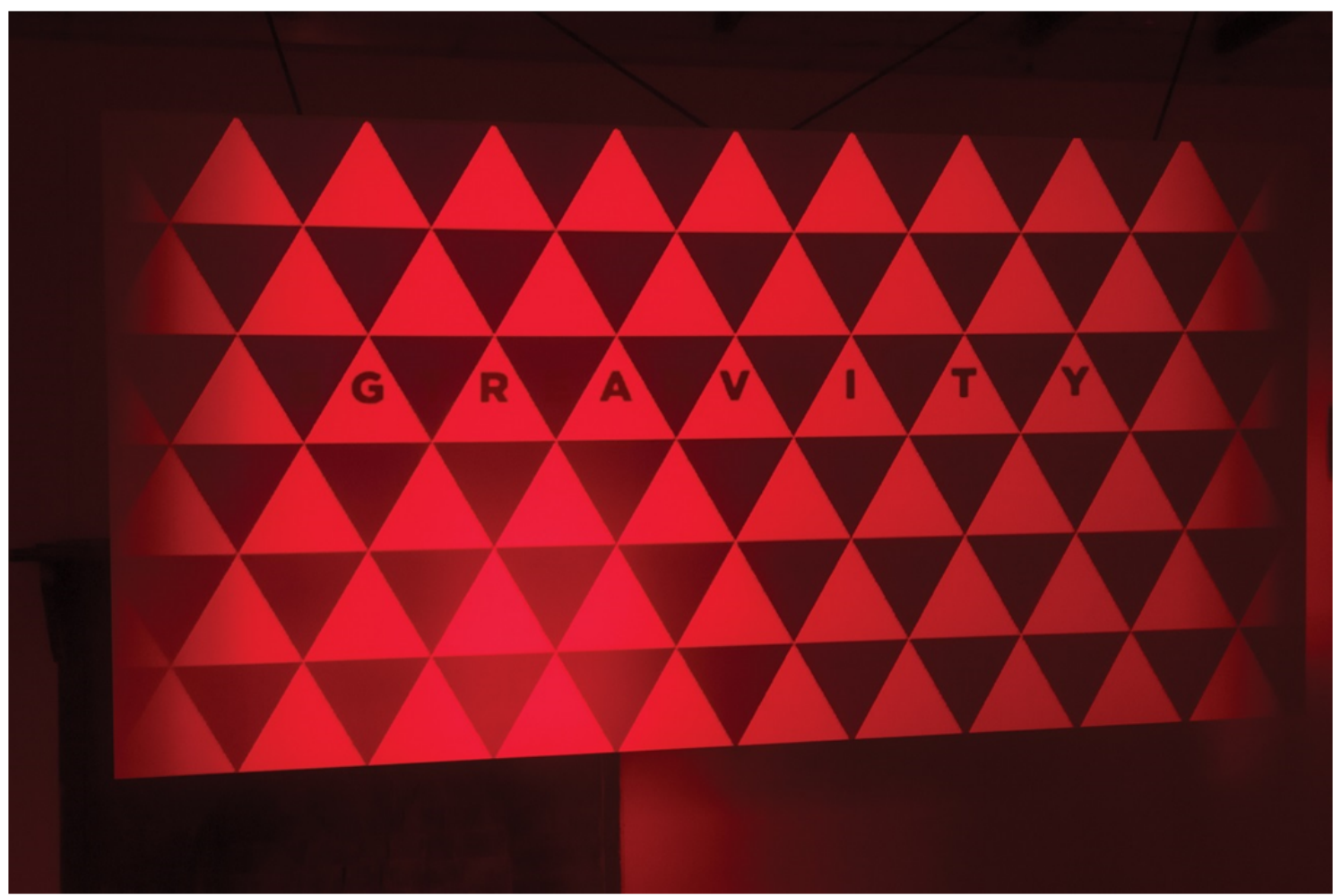

Figure 15. Projection as viewed through red coloured window pane, Human/Nature, Act 02: Global/Universal. Photograph courtesy lan Hill.

The Journal of Public Space, 4(3), 2019 | ISSN 2206-9658 | 167 City Space Architecture / UN-Habitat 
Act 03: Space/Time

Guided walk, map, audio

Location: Kyneton Botanic Gardens

A series of the Gardens artefacts were examined on this narrated walk to consider how they echo a broader relationship between humans and nature in shaping Earth, and the inspiration they provide to my artistic practice as examples of monumentality.

Each of the works highlighted the elastic tension of the forces that shape place.

Reiterating this idea through the use of dualities in their titles, I proposed dialectic enquiry for visitors to explore and seek a holistic 'true' representation of place (Kolodziejski, 20I5). The overarching duality of Human/Nature informs each work's siting: with the very 'human' environment of a derelict industrial factory, paired against a man-made reserve for 'nature' at the Gardens. While the factory housed introduced geologic and botanic material (setting up a tension between the introduced, and the endemic), the Gardens cottage contained an installation symbolising technology. The projection installation in the Gardens cottage Global/Universal drew on the narrative posed at the factory site, as the next frontier being Mars - further playing on the inward/outward thinking it poses with the duality to be discovered in the projection: eternity/gravity.

The Gardens walk Space/Time completed the audience journey with a contemplative walk that embodied the transformation of space into place over time (Alys 2004; Cardiff 199I; Smudge Studio 20 I I). The audio that accompanied the guided walk examined the deep-time origins of the Garden's botanical and architectural artefacts. The final artefact; a somewhat small Sierra Redwood tree - comparatively to redwoods in their native land of California: which are the largest living thing on Earth by volume. The first and largest redwoods discovered by colonisers in California were stripped of their bark for display in London (Delamotte, P.H. 1859), and cut down for their timber. The walk culminates in a provocation for the audience to build a kind of anti-monument to the redwood's destruction with their imagination:

"Today, scientists are undertaking the monumental task of sequencing the genomes of the coast redwood and giant sequoia in an effort to learn how to protect them against climate change and regenerate their forests. Like human beings, redwoods manifest a broad genetic range - no two are identical. Contrary to humans, the coast redwood genome is ten times larger than the human genome. Within the human body every cell contains an entire genome, and if each base pair of our genomes were side by side, they would span just over a meter. If we were to print out the data of our 3.1467 billion base pairs - the same data would fill I.2 million A4 single sided sheets, which would form a stack of around 130metres - towering just over the height of the Discovery Tree."

-Extract from audio Profit/Value, Act 03: Space/Time, Kyneton Botanic Gardens (Stanley, 2018) 


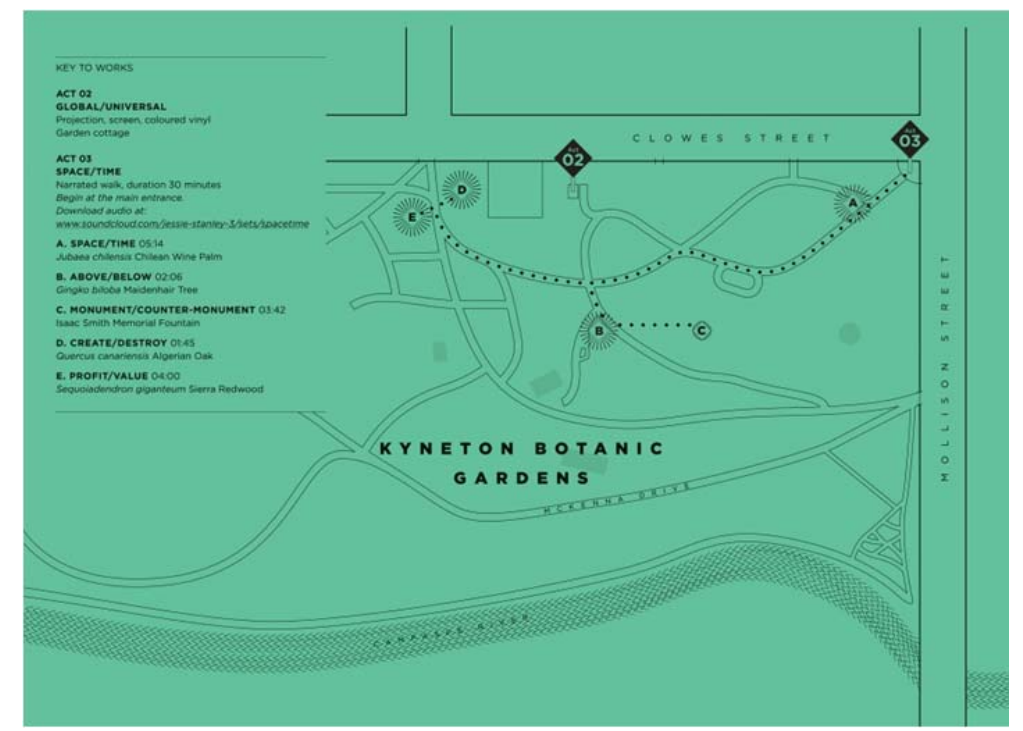

Figure 16. Map detail, Act 03: Space/Time, Jessie Stanley 2018.

\section{References}

Alÿs, F. (2004). Seven Walks, 2 I Portman Square, London; National Portrait Gallery, London.

Blake, W, \& Washington, W. J. (1968). Lines from the auguries of innocence, Bembridge.

Braidotti, R, Karvelas, P, (2018). 'The human and the posthuman', The Drawing Room, ABC, 17 April 2018. Available at: https://www.abc.net.au/radionational/programs/drawingroom/thehuman-and-the-posthuman/10616346.

Cardiff, J. (199I). Forest Walk, audio Walk $12 \mathrm{mins}$, Banff Centre for the Arts, Canadian Artist in Residence Program, Alberta, Canada.

Carrington, D. (2016). 'The Anthropocene epoch: scientists declare dawn of human-influenced age', The Guardian, 29 August, viewed 20 July 2018. Available at: https://www.theguardian.com/environment/2016/aug/29/declare-anthropocene-epochexperts-urge-geological-congress-human-impact-earth.

Connerton, P. (2008), 'Seven types of forgetting', Memory Studies, SAGE Publications, Los Angeles, London, New Delhi and Singapore, pp. 59-7I.

Cresswell, T. (2015). Place: an introduction, John Wiley \& Sons Ltd, UK.

Delamotte, P.H. (1859). Mother of the Forest in London Crystal Palace in 1859, English Heritage, digital image, viewed I5 December 2017, CC-PD-US. Available at: https://commons.wikimedia.org/wiki/File:Mother_of_the_Forest_in_London_Crystal_Palac e_1859.jpg.

Doherty, C. (2015). Out of Time, Out of Place: Public Art Now, Art Books Publishing and Situations, UK.

Farrier, D. (2016). 'How the concept of deep time is changing', The Atlantic. Availabe at: https://www.theatlantic.com/science/archive/2016/I0/aeon-deep-time/505922/. Accessed 31 October 2016.

Grant, B. (2016), Overview, () DigitalGlobe, Inc.

Hung, W. (2002). 'Mapping Contemporaneity in Asia-Pacific Art', Asia-Pacific Triennial, Queensland, Australia.

Kalman, T, Lasn, K, et al (1999). 'First Things First Manifesto 2000'. Eye, [Online] 9(33). Available at: www.eyemagazine.com/feature/article/first-things-first-manifesto-2000. Accessed 8 August 2018. 
Kolodziejski, L. (2015). 'What is Missing? Reflections on the Human-Nature Relationship in Maya Lin's Final Memorial', Environmental Communication, 9(4), pp. 428-445.

Lefebvre, H. (1968). The Sociology of Marx, Random House.

Lowenthal, D. (2015). 'Origins of Anthropocene Awareness', The Anthropocene Review 20I6, $3(1)$, Pp. 52-63.

Savage, K. (1999). 'The Past in the Present', Harvard Design Magazine, Issue 9: The Past in the Present. Available at: http://www.harvarddesignmagazine.org/issues/9/the-past-in-thepresent. Accessed on 29 July 2016.

Smudge Studio (20II). Geologic City: a Field Guide to the GeoArchitecture of New York, New York.

Stanley, J. (2018). Human/Nature, Act OI: Native/Foreign, Meteorological/ Geological. Ephemeral installation, bluestone aggregate and dust, local brown and grey dermosol soil, $5.6 \times 5.6 \mathrm{~m}$. Audio track 02:36. Location: Former Ajax Factory, 3I Beauchamp Street, Kyneton. Part of a series of participatory works in public space, Artist in Residence, Kyneton Botanic Gardens, Kyneton, Victoria.

Stanley, J. (2018). Human/Nature, Act 03: Space/Time (Space/Time 05:I4, Above/Below 02:06, Monument/Counter-Monument 03:42, Create/Destroy 01:45, Profit/Value 04:00). Guided walk, map, audio Location: Kyneton Botanic Gardens, Kyneton. Final act in a series of participatory works in public space, Artist in Residence, Kyneton Botanic Gardens, Kyneton, Victoria.

Stevens Q, Franck KA, Fazakerley R. (20I2). 'Counter-monuments: the anti-monumental and the dialogic', The Journal of Architecture, I7(6), pp. 95I-972.

Winter, J. (1999). 'Remembrance and redemption', Harvard Design Magazine, Issue 9: The Past in the Present. Available at: http://www.harvarddesignmagazine.org/issues/9/remembranceand-redemption. Accessed 29 July 2016.

Young, J.E. (1992). 'The Counter-Monument: Memory against itself in Germany today', Critical Inquiry, I8(2) (Winter), pp. 267-296.

Jessie Stanley lives and works in Central Victoria, Australia, and recently completed a major body of works as Artist in Residence at Kyneton Botanic Gardens in regional Victoria. Stanley's background in graphic design informs her socially engaged practice, which embraces the congruence of art in public space and graphic design as platforms for affecting the way meaning is produced within society. Upon completing a Bachelor of Visual Communication with First Class Honors at Monash University in 200I, Stanley undertook an internship at Fabrica in Italy in 2002; and then established her design studio Foundry (2003-20I2), in Melbourne Australia. Her design/visual art projects have received international recognition; awards include the Type Directors Club of New York, Premiers Design Awards, and Australian Graphic Design Association, and have been exhibited internationally. In 2018 Stanley was awarded Master of Arts (Art in Public Space) with Distinction at RMIT University, and the Vice Chancellors List for Academic Excellence.

Through typography, mapping, projection, and narrative, Stanley creates ephemeral works about place that contextualise our human experience within deep time and interstellar space. Works are site responsive and developed through an intensive process of historiographic and geographic research, underpinned by scientific theory. Unearthing the forces that shape place; Stanley stages scenarios that encourage curiosity in the sublime relationship we have with our environment.

http://www.jessiestanley.com 